\title{
Do climatic oscillations influence cyclical patterns of soft bottom macrobenthic communities on the Swedish west coast?
}

\author{
Björn G. Tunberg ${ }^{1, *}$, Walter G. Nelson ${ }^{2, * *}$ \\ ${ }^{1}$ Kristineberg Marine Research Station, Kristineberg 2130, S-450 34 Fiskebäckskil, Sweden \\ ${ }^{2}$ Division of Marine and Environmental Systems, Florida Institute of Technology, Melbourne, Florida 32901, USA
}

\begin{abstract}
Soft sediment macrofauna has been monitored at 10 stations (10 to $300 \mathrm{~m}$ ) off the west coast of Sweden for periods of 12 to $20 \mathrm{yr}$. Macrobenthic abundance and biomass in this region show a distinct cyclical pattern of approximately 7 to $8 \mathrm{yr}$. Macrobenthic oscillation patterns down to $100 \mathrm{~m}$ depth are generally in phase, suggesting a causative mechanism operating at a regional scale. A.t the $300 \mathrm{~m}$ deep station, the cycles did not appear to be in phase with the stations in shallower water. Spectral analysis of the 130 yr record of the North Atlantic Oscillation (NAO) index indicated that the dominant component of the index occurred at a period of 7.9 yr. The NAO index over the period 1970 to 1990 was significantly positively correlated with Skagerrak deep water $(600 \mathrm{~m})$ temperature and significantly negatively correlated with stream flow from western Sweden. Stream flow was significantly positively correlated with benthic abundance and biomass at stations down to $100 \mathrm{~m}$ depth, but negatively correlated with bottom water oxygen content. We therefore propose that climatological linkages affecting primarily surface primary production result in bottom-up control of benthic population changes. We suggest that climatic variability in the region may be a more basic causative factor for benthic disturbance than eutrophication and other possible factors which have previously been proposed.
\end{abstract}

KEY WORDS: Benthos - Infauna Cycles - Oscillation - Climate NAO index

\section{INTRODUCTION}

Variability of population abundances is a typical feature of marine pelagic and benthic ecosystems at a variety of temporal scales (Cushing 1981, Botsford et al. 1982, Gray \& Christie 1983, Baumgartner et al. 1992). Climatological factors are believed to be responsible for many aspects of temporal variability of marine communities (Aebischer et al. 1990, Francis \& Hare 1994, Beamish et al. 1995, Stein \& Lloret 1995, Ware 1995), including cyclical patterns of variation in some populations (Gray \& Christie 1983). The El Niño South-

\footnotetext{
-E-mail: b.tunberg@kmf.gu.se

- Present address: Coastal Ecology Branch, Western Ecology Division, US Environmental Protection Agency, Hatfield Marine Science Center, 2111 S.E. Marine Science Drive, Newport, Oregon 97365-5260, USA.
}

ern Oscillation (ENSO) is a well known source of climatologically driven variation in marine populations (Barber \& Chavez 1983, Cane 1983, Dayton \& Tegner 1984, Tarazona et al. 1988a, b, Philander 1989). The comparable role of periodic climatological variation in regulating physical and biological oceanographic processes in the North Atlantic region has been increasingly studied in recent years. Recent modeling suggests that there may be predictable climatic influences on North Atlantic sea surface temperature at time scales of a decade or longer (Hansen \& Bezdek 1996, Griffies \& Bryan 1997, Sutton \& Allen 1997). Proposed linkages of climate to biological processes include the long-term increase in the northerly wind component over the eastern North Atlantic in recent years as an influence on phytoplankton and zooplankton biomass (Dickson et al. 1988), and the relation of westerly weather in the North Atlantic to long-term 
trends in phytoplankton, zooplankton and seabird colonies (Aebisher et al. 1990).

The large scale ocean-atmosphere variation associated with the ENSO in the southern hemisphere appears to be linked to similar periodic variation in the North Atlantic region (Rogers 1984). The North Atlantic Oscillation (NAO) was described by Walker in the 1920s, and is defined by Rogers (1984) as 'the temporal fluctuation of the zonal wind strength across the Atlantic Ocean due to pressure variations in both the subtropical anticyclone belt and in the subpolar low near Iceland'. Consequences of the NAO include periodic variation in the winter temperatures and precipitation levels of northern Europe. Periodic alteration of sea surface temperature and coastal runoff provide potential linkages of climate variation to changes in pelagic and benthic populations of the coastal zone in this region.

The National Marine Monitoring Program of the Swedish Environmental Protection Agency has sam- pled a network of soft-sediment community stations off the west coast of Sweden since 1983, with collections from selected stations extending from 1973. Analysis of data collected by this program up to the 1980s (Josefson 1990) found significant increases in benthic community abundance and biomass which were positively correlated with nutrient discharge from Swedish rivers to the coastal ocean. However, subsequent to the mid1980 s these benthic parameters decreased, only to rebound again in the 1990s (Tunberg unpubl. data).

Based on statistical analysis of the long-term benthic monitoring data, we present evidence that there is a periodic component for benthic community parameters, and that this periodicity is generally temporally synchronized among stations within different depth ranges. We propose that the periodic behavior of benthic community parameters is driven by periodicity at similar time scales for meteorological conditions within the North Atlantic region.

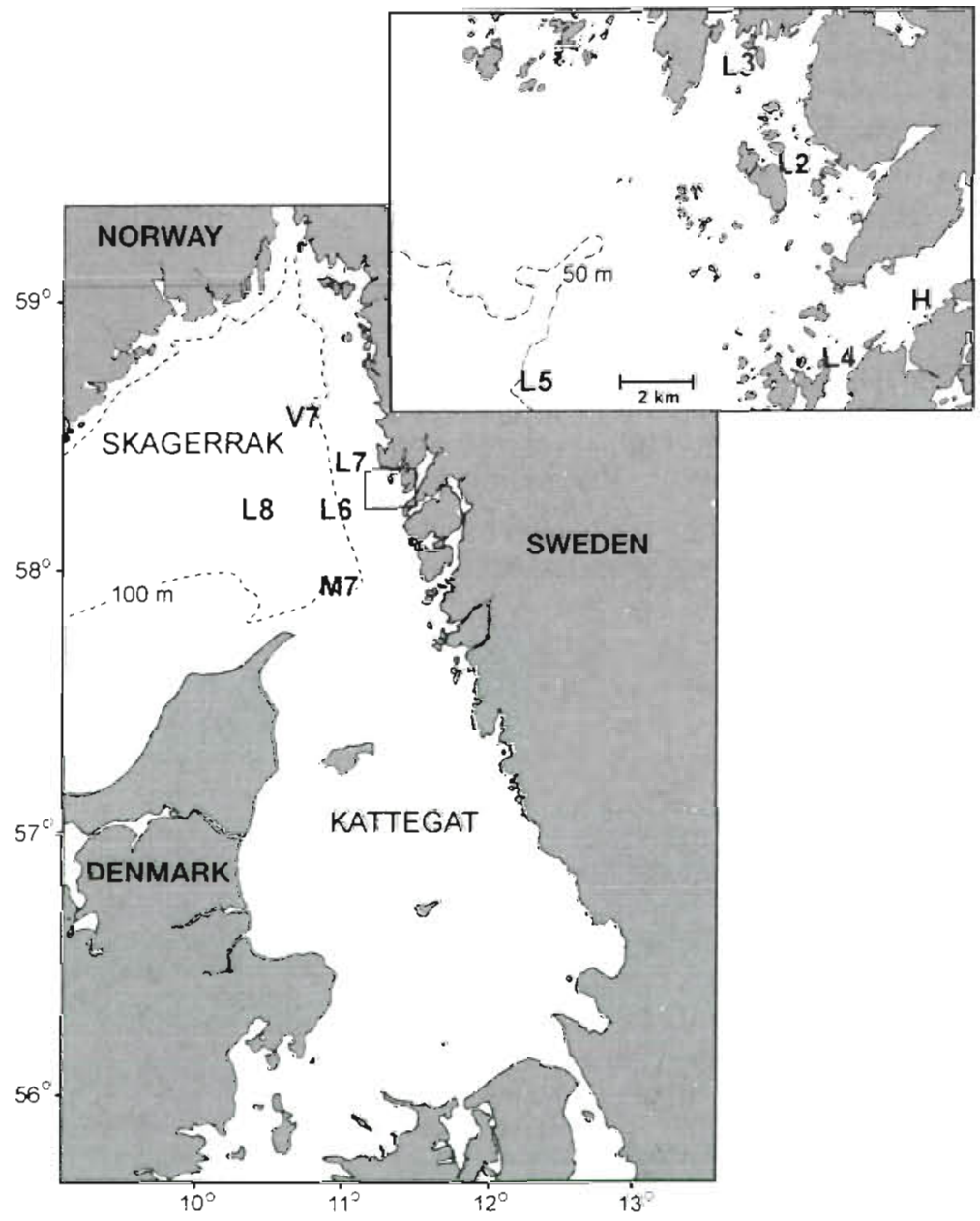

Fig. 1. Location of sampling stations along the Swedish west coast. The small rectangle shows the location of the enlarged area (at the mouth of Gullmarsfjorden) presented in the upper right corner

\section{MATERIALS AND METHODS}

Ten stations were sampled within varying depth zones off the central west coast of Sweden (Fig. 1). Data from 9 stations (L2, L3, L4, H, L5, L7, L6, M7, V7) sampled once per year in May in the $12 \mathrm{yr}$ period from 1983 through 1994 (except $M 7$ in 1983) and data from 1 additional deep $(300 \mathrm{~m})$ station (L8) sampled over the 20 yr period from 1973 to 1993 were analyzed. Stn L8 was sampled quarterly from 1973 to 1976 , biannually in 1977 . 1981 and 1982, and once per year in 1978 to 1980 and 1983 to 1993 . Sampling was discontinued at Stn L8 subsequent to 1993 due to financial limitations.

At each station 5 quantitative sediment samples for biological analysis were collected with a modified Smith-McIntyre grab $\left(0.1 \mathrm{~m}^{2}\right)$ weighing $70 \mathrm{~kg}$. The faunal samples were washed on a $1 \mathrm{~mm}$ mesh sieve, and material retained was preserved in the field ( $4 \%$ buffered formalinsea water solution).

In the laboratory, each grab sample was divided into 2 size fractions ( $\geq 2 \mathrm{~mm}, 1$ to $2 \mathrm{~mm}$ ) by resieving in fresh water with nested sieves. The larger fraction was sorted by hand in a large white pan, while the smaller fraction was sorted under a stereo microscope ( $\times 6$ magnification). All animals were generally identified to the species level, counted, and total wet 
Table 1. Position and description of long-term benthic monitoring stations on the west coast of Sweden

\begin{tabular}{|lcccl|}
\hline Station & Lat. (N) & Long. (E) & Depth (m) & Substrate \\
\hline L2 & $58^{\circ} 18.48^{\prime}$ & $11^{\circ} 24.13^{\prime}$ & 18 & Clayey mud \\
L3 & $58^{\circ} 20.36^{\prime}$ & $11^{\circ} 21.44^{\prime}$ & 27 & Clayey mud \\
L4 & $58^{\circ} 14.68^{\prime}$ & $11^{\circ} 25.58^{\prime}$ & 40 & Sandy mud \\
H & $58^{\circ} 15.81^{\prime}$ & $11^{\circ} 28.66^{\prime}$ & 30 & Sandy mud \\
L5 & $58^{\circ} 14.40^{\prime}$ & $11^{\circ} 15.00^{\prime}$ & 50 & Sandy mud \\
L7 & $58^{\circ} 22.90^{\prime}$ & $11^{\circ} 09.20^{\prime}$ & 50 & Sandy mud \\
V7 & $58^{\circ} 32.50^{\prime}$ & $10^{\circ} 47.50^{\prime}$ & 100 & Clayey mud \\
L6 & $58^{\circ} 15.20^{\prime}$ & $11^{\circ} 03.50^{\prime}$ & 100 & Sandy mud \\
M7 & $57^{\circ} 55.90^{\prime}$ & $11^{\circ} 02.50^{\prime}$ & 100 & Clayey mud \\
L8 & $58^{\circ} 14.90^{\prime}$ & $10^{\circ} 34.30^{\prime}$ & 300 & Mud \\
\hline
\end{tabular}

weight of each species was determined after blotting to remove excess water. For practical reasons biomass was always expressed without certain very large species (e.g. Nephrops norvegicus, Arctica islandica, Brissopsis lyrifera, Ecinocardium spp.) that completely obscured the biomass contributions of other species. Sorted and identified samples were transferred to $70 \%$ ethanol and archived.

In order to detect trends which were most representative of regional processes, stations were combined for analysis into groups based on similar depths (Table 1). The groups were (1) L2, L3, L4, H (inshore <40 m), (2) L5, L7 (50 m), (3) L6, M7, V7 (100 m), and Stn L8 $(300 \mathrm{~m})$. For a group of stations the mean abundance values, representing all replicate grabs at a single station, were first averaged for all stations within a given sampling year to form a single time series for the group. Time series were 12 yr (1983 to 1994) for inshore and $50 \mathrm{~m}$ groups, and 11 yr (1984 to 1994) for the $100 \mathrm{~m}$ group because no sample was obtained from Stn $M 7$ in 1983. The mean and standard deviation for all dates for the combined time series were computed, and these values were used to convert the abundance for each year into a standard normal deviate value (see e.g. Sokal \& Rohlf 1981) Conversion of all data into standard deviates allows data from sites differing substantially in absolute abundance to be presented on the same abundance axis and allows a more ready visual comparison of trends. Abundance or biomass data were analyzed by least squares polynomial regressions using SigmaPlot $\circledast$ for Windows software. The best fit polynomial regression was determined from the $F$ tests of the incremental and overall residual mean squares for each order of the regression using SigmaStat $\circledast^{\circledR}$ for Windows software (see Table 2 for an example).

An index of the magnitude of the NAO, the NAO index, is calculated as the difference between the normalized mean winter (Dec, Jan, Feb) atmospheric pressure anomalies at Ponta Delgadas, Azores and Akureyri, Iceland (Rogers 1984). Index values were
Table 2. Example of incremental and overall stepwise polynomial regression results for regression orders 0 to 8 for the inshore $(<40 \mathrm{~m})$ stations

\begin{tabular}{|lccccc|}
\hline $\begin{array}{l}\text { Regression } \\
\text { order }\end{array}$ & \multicolumn{1}{l}{ Incremental } & & Overall & \\
& $F$ & $\mathrm{p}$ & $F$ & $\mathrm{p}$ & $\mathrm{r}^{2}$ \\
\hline 0 & 0.00 & 0.00 & 0.00 & 0.00 & 0.00 \\
1 & 7.55 & 0.02 & 7.55 & 0.02 & 0.43 \\
2 & 0.00 & 0.95 & 3.40 & 0.10 & 0.43 \\
3 & 0.09 & 0.77 & 2.07 & 0.19 & 0.44 \\
4 & 13.03 & 0.01 & 7.15 & 0.03 & 0.80 \\
5 & 0.16 & 0.71 & 5.06 & 0.07 & 0.81 \\
6 & 0.01 & 0.93 & 3.52 & 0.12 & 0.81 \\
7 & 0.03 & 0.88 & 2.43 & 0.19 & 0.81 \\
8 & 0.79 & 0.44 & 2.12 & 0.24 & 0.85 \\
\hline
\end{tabular}

computed for the period 1875 to 1995 from data kindly provided by DrJ. C. Rogers. Periods when the NAO index is below the long-term mean (Fig. 2) are associated with lower winter temperatures in Scandinavia and with a greater intensity of the westerlies during spring over the northeast Atlantic (van Loon \& Rogers 1978, Rogers 1984, Kerr 1997). The time series of the NAO index was subjected to Fourier analysis to determine the major periodic components of this climatological index.

Cross correlation analysis between abundance or biomass and a variety of either climatological or biological variables were conducted for time lags between -15 and +15 yr using Statistica ${ }^{\circledR}$ for Windows software.

Physical data for cross correlation analyses were obtained from a variety of sources. Data for total annual combined flow from all major streams along the

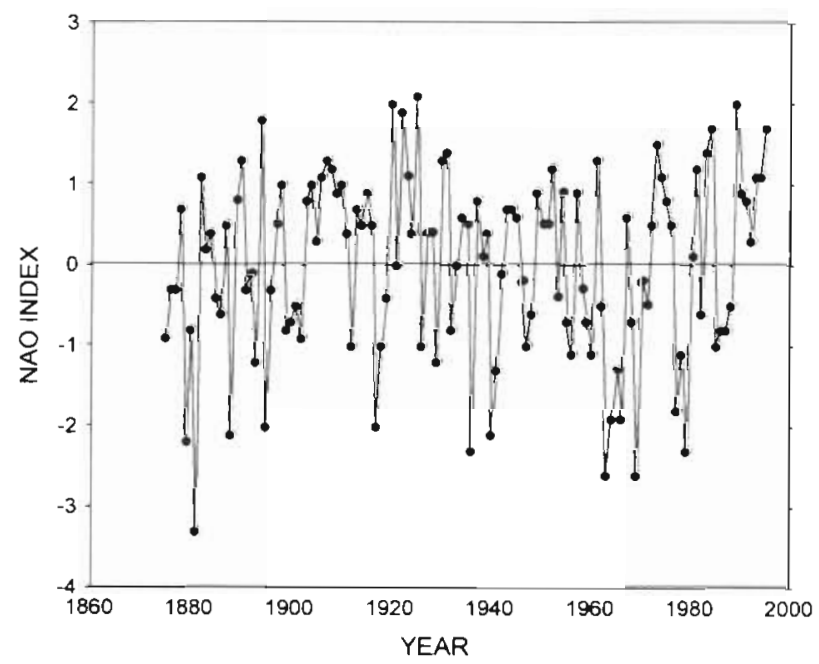

Fig. 2. North Atlantic Oscillation (NAO) index values between 1875 and 1995 calculated as the difference between the normalized mean winter (Dec, Jan, Feb) atmospheric pressure anomalies at Ponta Delgadas (Azores) and Akureyri (Iceland) 


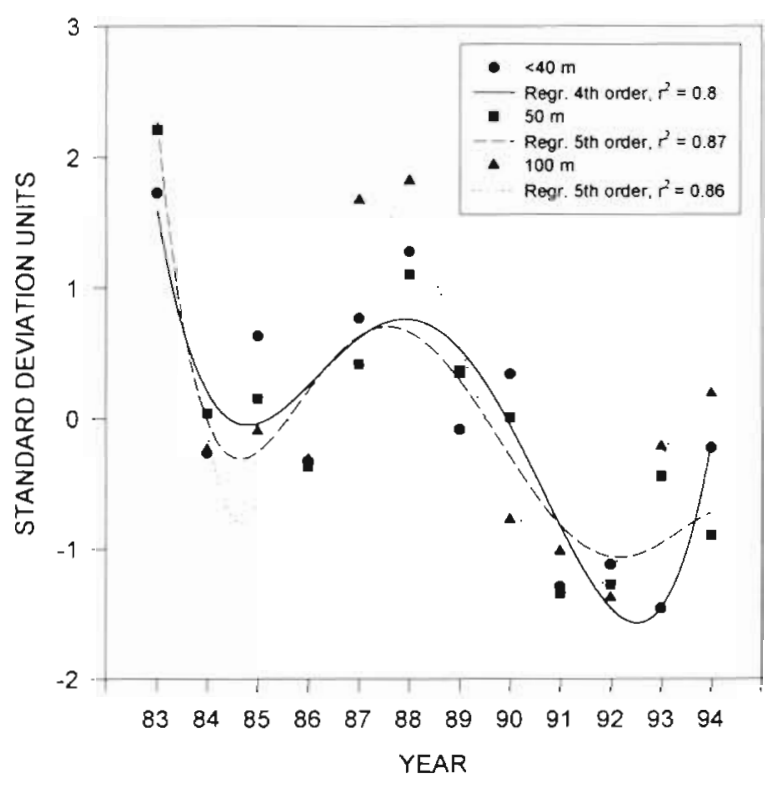

Fig. 3. Least squares polynomial regressions for normalized total abundance of macrobenthos between 1983 and 1994 for 3 sets of stations grouped by depth intervals $(<40 \mathrm{~m}=$ $\mathrm{L} 2, \mathrm{~L} 3, \mathrm{~L} 4, \mathrm{H}, 50 \mathrm{~m}=\mathrm{L} 5, \mathrm{~L} 7 ; 100 \mathrm{~m}=\mathrm{L} 6, \mathrm{M} 7, \mathrm{~V} 7$ )

west coast of Sweden for the period 1970 to 1994 were obtained from the Swedish Meteorological and Hydrological Institute. Stream flow data were first converted to standard normal deviates, and then smoothed by a 3 point moving average. The data were then detrended to remove a linear trend from the data set using the empirically calculated transformation for the stream flow data set (Ydetrended $=Y-0.925-0.062 \times$ time). Smaller subsets of the stream flow data for the time periods corresponding to benthic sample data were smoothed with 2 point moving averages.

Data for temperature in the Skagerrak deep water $(600 \mathrm{~m})$ off the coast of Norway were obtained for the period 1947 to 1990 from a publication of the North Sea Task Force (1993). The water at this depth is located below the sill depth of the Skagerrak $(270 \mathrm{~m})$ and variations in temperature are indicative of climatic variations (North Sea Task Force 1993). A subset of the data from 1970 to 1990 , covering most of the period of benthic sampling in this study, was used in analyses. Published values of mean bottom water oxygen concentration from 31 stations along the Skagerrak coast of Norway were obtained from Fig. 6 of Johannessen \& Dahl (1996) for the period 1977 to 1993 and were smoothed with a 2 point moving average.

Fish and shellfish landing data for the west coast of Sweden over the period 1980 to 1995 were obtained from the Swedish Statistical Central Bureau (SCB), Orebro. Data on crustacean landings were smoothed with a 2 point running average prior to cross correlation analysis.

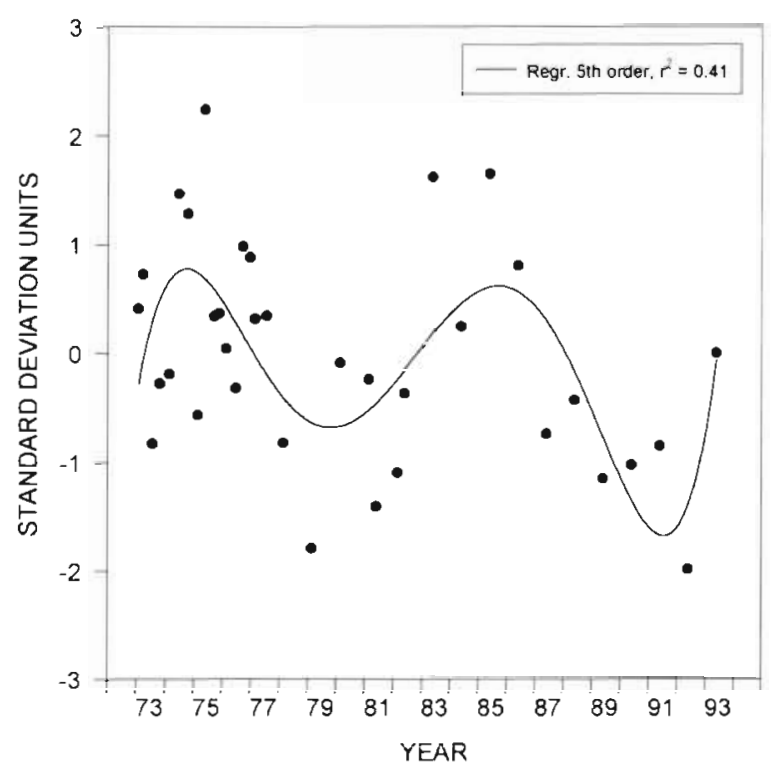

Fig. 4. Least squares polynomial regression for normalized total abundance of macrobenthos between 1973 and 1993 for Stn L8 (300 m)

\section{RESULTS}

In all cases the best fit polynomial regression analyses for abundance at the 3 groups of stations were non linear (Fig. 3), either a 4th order polynomial (inshore stations) $\left(\mathrm{r}^{2}=0.80, \mathrm{p}=0.03\right)$, or a 5 th order polynomial function (50 m: $\mathrm{r}^{2}=0.87, \mathrm{p}=0.03 ; 100 \mathrm{~m}: \mathrm{r}^{2}=0.86, \mathrm{p}=$ 0.056 ), accounting for $\geq 80 \%$ of total variance in the data sets. Peak benthic abundances at all stations occurred in 1988, followed by a decrease to a minimum in 1991 to 1992 , and a subsequent increase through 1994, suggesting a cycle with a period of approximately 7 to 8 yr.

Abundance at Stn L8 showed a significant fit to a 5th order polynomial regression (Fig. 4), although the intraannual variation present during the first decade of sampling greatly reduced the goodness of fit compared to the other groups of stations $\left(r^{2}=0.41, p=0.056\right)$. Peaks of abundance were seen in the periods 1975 to 1976 and 1983 to 1985, suggesting a cycle length of approximately 7 to $9 \mathrm{yr}$. The lack of samples subsequent to 1993 at Stn L8 prevents the confirmation of a suggested upturn in abundance at this time. Comparison of the timing of peaks at Stn L8 versus other stations showed a temporal offset of about minus $3 \mathrm{yr}$.

The temporal pattern of change in biomass at the inshore stations differed both from the abundance data and from the biomass data at all other sets of stations (Fig. 5). The 50 and $100 \mathrm{~m}$ stations showed clear minima in the periods 1983 to 1985 and 1991 to 1992, and maxima in the periods 1988 to 1989 and 1993, a pattern 


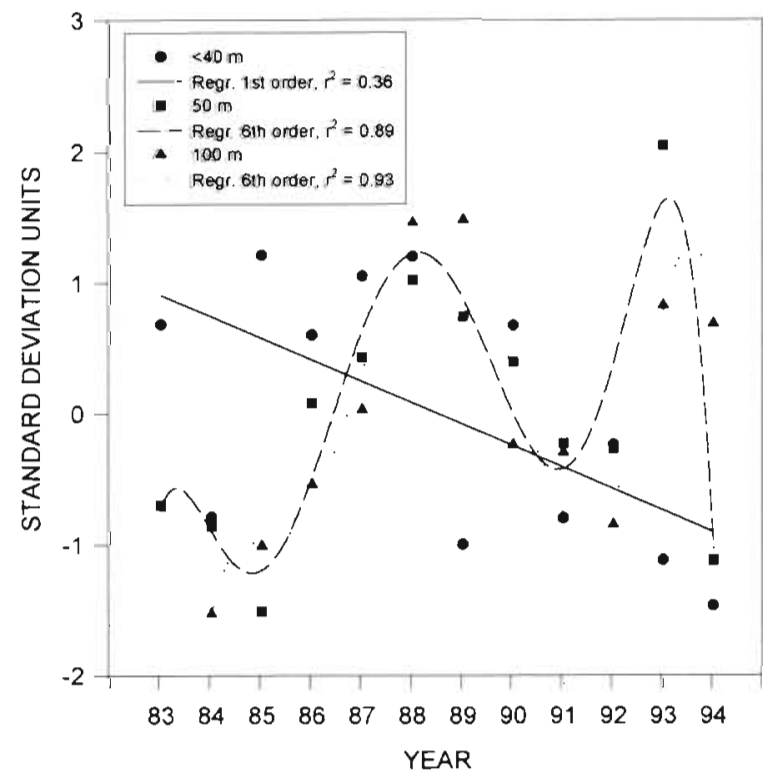

Fig. 5. Least squares polynomial regressions for normalized total biomass of macrobenthos between 1983 and 1994 for 3 sets of stations grouped by depth intervals $(<40 \mathrm{~m}=$ L2, L3, L4, H; $50 \mathrm{~m}=\mathrm{L} 5, \mathrm{~L} 7 ; 100 \mathrm{~m}=\mathrm{L} 6, \mathrm{M} 7, \mathrm{~V} 7$ )

Consistent with a cyclical component of period 7 to $9 \mathrm{yr}$. Oscillations at both sets of stations showed significant fits to 6th order polynomial regressions $\left(\mathrm{r}^{2}=0.89, \mathrm{p}=\right.$ 0.048 and $r^{2}=0.93, p=0.041$ ) explaining $\geq 89 \%$ of total variance in the data sets. In contrast, the biomass at the inshore stations was best fit by a 1st order (linear) regression $\left(\mathrm{r}^{2}=0.36, \mathrm{p}=0.04\right)$ explaining relatively little of total variation in the data. Stn L2 biomass showed the highest deviation from the general pattern of the other 3 shallow stations. When Stn L2 was excluded from the calculations the best fit was achieved by a 2 nd order polynomial regression $\left(\mathrm{r}^{2}=\right.$ $0.61, p=0.03$ ), with a peak value in 1987 to 1988 .

Biomass at the deep station (L8) was best fit by a 5 th order polynomial regression (Fig. 6), although again the intraannual variation present during the first decade of sampling greatly reduced the goodness of fit compared to the other stations $\left(\mathrm{r}^{2}=0.52, \mathrm{p}=0.018\right)$. Peaks in biomass occurred in 1976 to 1977 and 1983 to 1986, again consistent with an oscillatory component with a 7 to 9 yr period. Biomass peaks at Stn L8 were in phase with those for abundance at this station, but approximately minus 3 yr out of phase with the 50 and $100 \mathrm{~m}$ stations.

Spectral analysis of the $130 \mathrm{yr}$ record of the NAO index indicated that the dominant oscillatory component of the index occurred at a period of $7.9 \mathrm{yr}$.

The NAO index over the period 1970 to 1990 was significantly positively correlated with lag -1 yr Skagerrak deep water $(600 \mathrm{~m}$ ) temperature (Fig. 7). Over

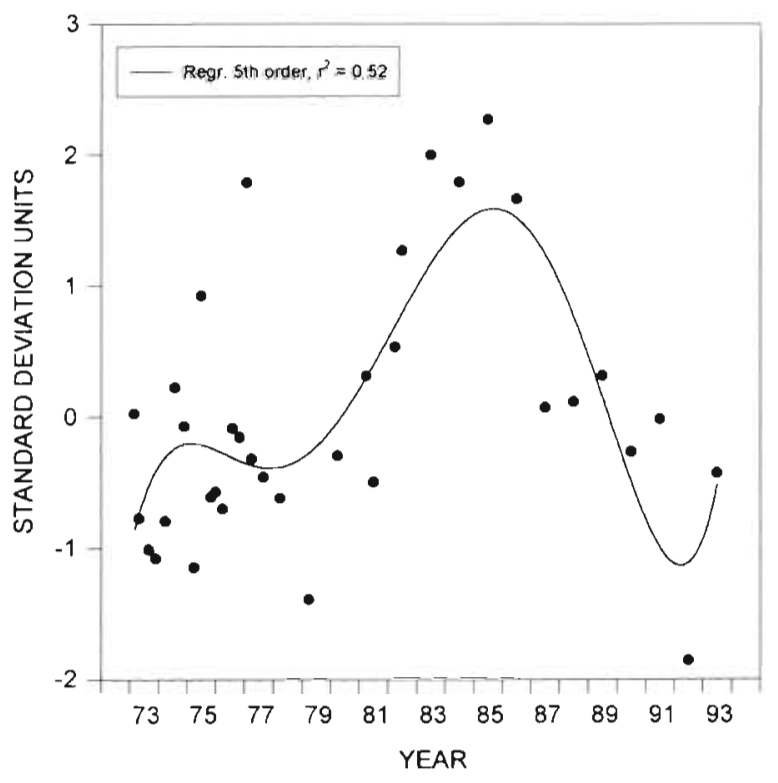

Fig. 6. Least squares polynomial regression for normalized total biomass of macrobenthos between 1973 and 1993 for Stn L8 (300 m)

the same time period the smoothed NAO index was significantly negatively correlated with stream flow from western Sweden at lags of $0,-1$ and $-2 y r$, with the largest correlation occurring for stream flow at lag -1 yr (Fig. 8). In turn, mean bottom water oxygen concentration from the Norwegian coast of the Skagerrak was significantly negatively correlated with stream flow at lags of 0 and +1 yr (Fig. 9).

Stream flow was significantly positively correlated with benthic abundance and biomass at inshore, 50 and $100 \mathrm{~m}$ stations at lags of either 0 or -1 yr (Table 3 ).

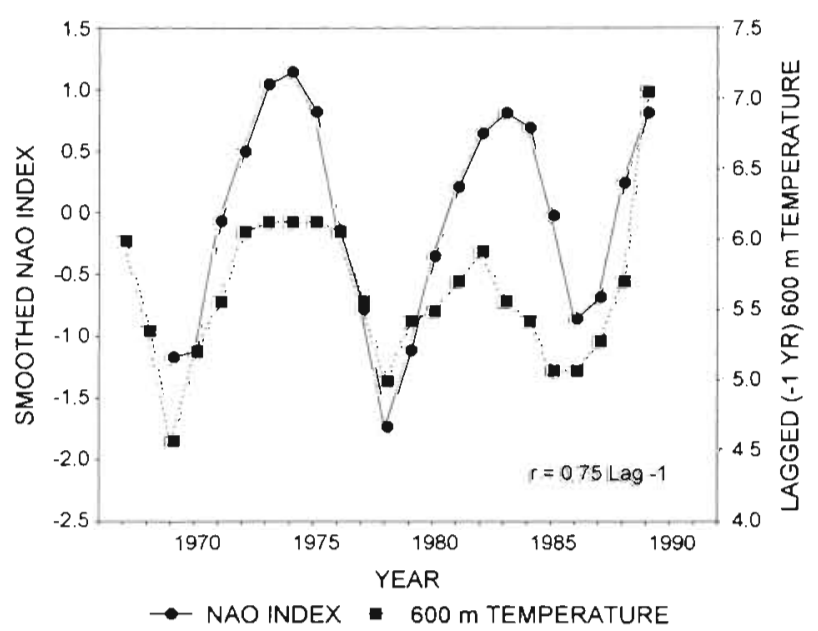

Fig. 7. Correlation between the NAO index values (smoothed) and $600 \mathrm{~m}$ temperature values in the Skagerrak (lag $-1 \mathrm{yr}$ ) 


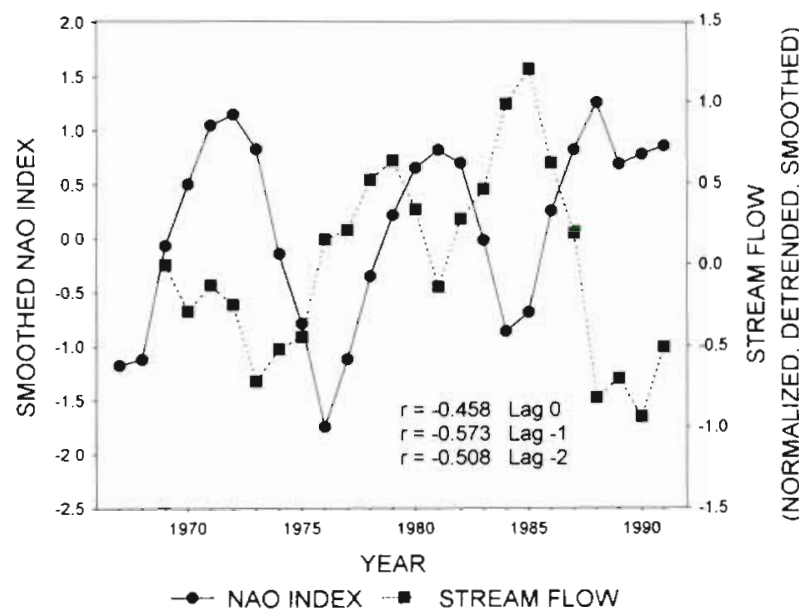

Fig. 8. Correlation between the NAO index values (smoothed) and the total stream flow data (normalized, detrended, smoothed) from the rivers on the Swedish west coast

There were significant correlations of stream flow with abundance and biomass at the deep station $\mathrm{L} 8$, but these correlations were for lag $+2 \mathrm{yr}$, and were thus out of phase with the stations closer to the coast (Table 3 ).

Abundance and biomass values were significantly correlated with the NAO index, but with different time lags at different depth intervals (Table 4).

In order to elucidate possible interactions between benthic infauna and other available biological long-term data series a comparison was made with fish landing data (total yearly catches along the Swedish west coast). These preliminary analyses showed e.g. that there was a strong positive correlation between benthic inshore abundances and cod landings (Fig. 10), and a strong negative correlation between benthic inshore abun-

Table 3. Time lags assoriated with significant $(p<0.05)$ correlations between total annual flow from all major streams along the Swedish west coast with mean macrobenthic community abundance and biomass from long-term monitoring stations. Letters indicate transformations applied to the stream flow variable. $S=$ smoothed by 2 point moving average, $\mathrm{D}=$ linear trend removed from data

\begin{tabular}{|lll|}
\hline Stns & Abundance & Biomass \\
\hline $\begin{array}{lll}\text { Inshore } \\
\text { L2, L3, L4, H }\end{array}$ & $0.60(\operatorname{lag} 0)$ & $0.70(\operatorname{lag} 0)$ \\
$50 \mathrm{~m}$ & $0.85(\operatorname{lag}-1) \mathrm{S}$ & $0.82(\operatorname{lag}-1) \mathrm{S}, \mathrm{D}$ \\
$\mathrm{L} 5, \mathrm{~L} 7$ & $0.68(\operatorname{lag} 0) \mathrm{S}$ & \\
$100 \mathrm{~m}$ & $0.72(\operatorname{lag} 0)$ & $0.74(\operatorname{lag}-1) \mathrm{S}, \mathrm{D}$ \\
$\mathrm{L} 6 . \mathrm{M} 7, \mathrm{~V} 7$ & $0.75(\operatorname{lag}+2)$ & $0.72(\operatorname{lag}+2)$ \\
$300 \mathrm{~m}$ & & \\
L8 &
\end{tabular}

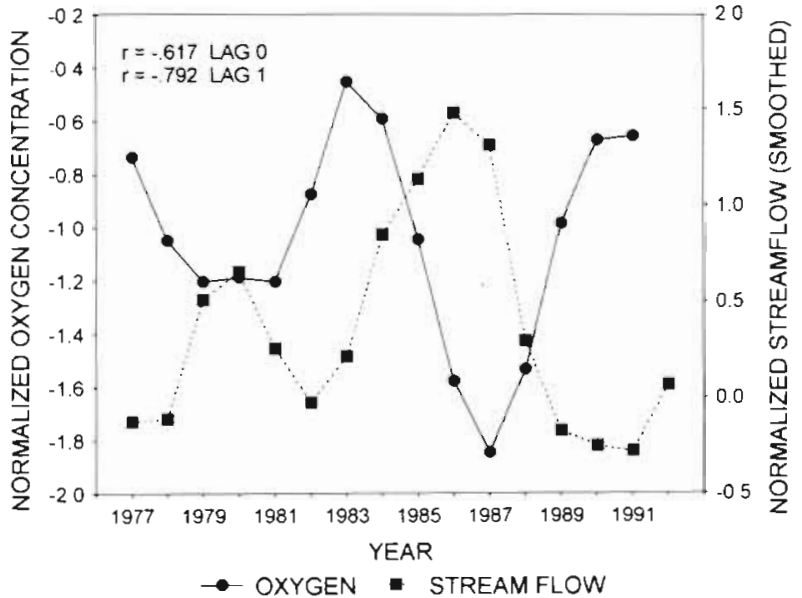

Fig. 9. Correlation between mean oxygen concentrations (normalized) from 31 stations along the Skagerrak coast of Norway and normalized stream flow data (see Fig. 8)

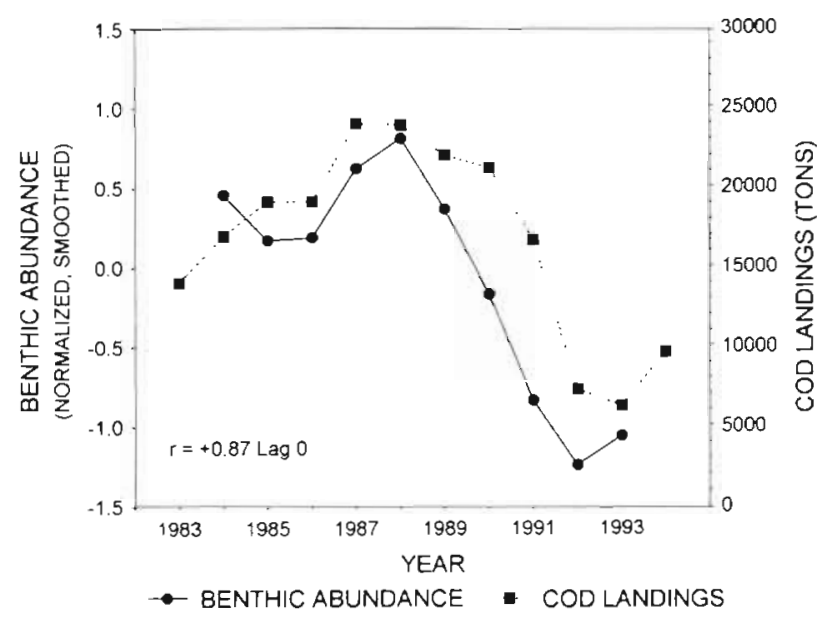

Fig. 10. Correlation between total abundance values (normalized, smoothed) at the 4 inshore stations L2, L3, L4, H combined and cod landings on the Swedish west coast

Table 4. Time lags associated with significant $(p<0.05)$ correlations between NAO index values with mean macrobenthic community abundance and biomass from long-term monitoring stations

\begin{tabular}{|c|c|c|}
\hline Stns & Abundance & Biomass \\
\hline $\begin{array}{l}\text { Inshore } \\
\text { L2, L3, L4, H }\end{array}$ & $-0.88(\operatorname{lag}-2)$ & $-0.70(\operatorname{lag} 0)$ \\
\hline $\begin{array}{l}50 \mathrm{~m} \\
\mathrm{~L} 5, \mathrm{~L} 7\end{array}$ & $-0.59(\operatorname{lag}+3)$ & $+0.72(\operatorname{lag}+2)$ \\
\hline $\begin{array}{l}100 \mathrm{~m} \\
\text { L6, M7, V7 }\end{array}$ & $-0.62(\mathrm{lag}-2)$ & $+0.73(\operatorname{lag}+1)$ \\
\hline $\begin{array}{l}300 \mathrm{~m} \\
\mathrm{~L} 8\end{array}$ & $-0.72(\mathrm{lag}+2)$ & $-0.80(\operatorname{lag}+2)$ \\
\hline
\end{tabular}




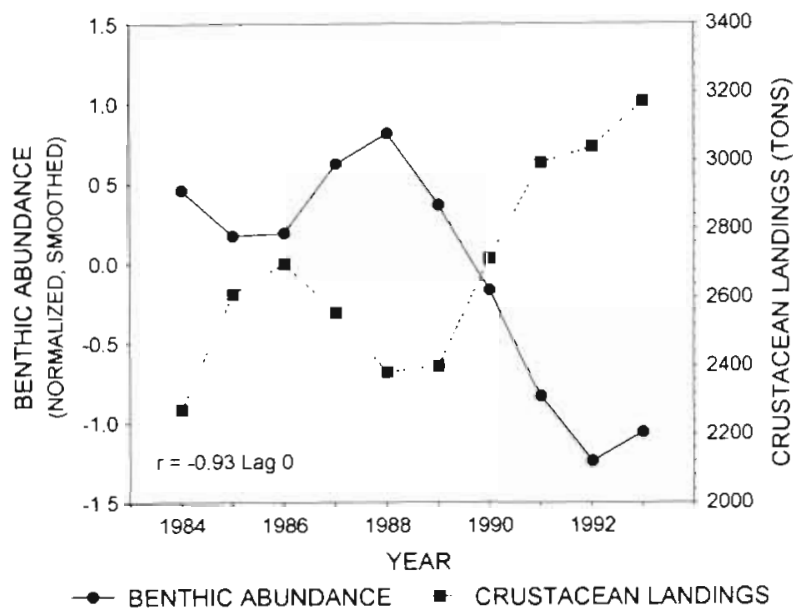

Fig. 11. Correlation between total abundance values (normalized, smoothed) at the 4 inshore stations L2, L3, L4, H combined and commercial crustacean landings on the Swedish west coast

dances with crustacean landings (Fig. 11). However, no significant correlation was found between cod landings and crustacean landings (directly or at any time lag).

\section{DISCUSSION}

The fact that many marine benthic populations exhibit periodic variation in abundance at a variety of temporal scales was clearly summarized by Gray \& Christie (1983). Further examples are the temporal trends of abundance and biomass of benthos off the Swedish west coast over the period 1983 through 1993, which are best described at most stations by higher polynomial functions indicating an important periodic component to these macrobenthic community parameters. The simple linear regression models previously used (Josefson 1990) to describe temporal trends in earlier segments of the data from these stations may not have been adequate to describe the complex temporal behavior of abundance and biomass trends, a point partly reflected in the criticism by Gray (1990) on the interpretation of these data.

With the exception of biomass at the inshore stations, groups of stations from $18 \mathrm{~m}$ down to $100 \mathrm{~m}$ depth all showed cyclical patterns of abundance and biomass with periods of approximately 7 to $8 \mathrm{yr}$, and the cycles were in phase. That oscillations were in phase at stations spread over an area of more than $1500 \mathrm{~km}^{2}$ indicates that large scale processes are important drivers of the pattern. A similar oscillatory pattern with a 7 yr period has been reported for the abundance of the benthic amphipod Pontoporeia affinis in the Bothnian Sea of the Baltic over the period 1961 to 1974 (Gray \& Christie 1983).
Abundance and biomass of the deepest station $(300 \mathrm{~m})$ also showed evidence of cyclical patterns, although the cycles did not appear to be in phase with those of the stations in depths of $100 \mathrm{~m}$ or less. While it is tempting to attribute this difference to some function of depth, the fact that only 1 deep station was sampled greatly limits the ability to generalize.

The correlations noted in this paper between the NAO index as an indicator of climatic variation, variations of physical parameters in the marine environment, and variation patterns in biological populations offer potentially important insight into the regulation of coastal nearshore communities. However, when correlations between benthic populations parameters and the NAO index are directly calculated, significant correlations are found but the sign and lag of these correlations are variable and difficult to interpret (Table 4). This may be partly due to the limited number of sample stations available at some depths (e.g. $50 \mathrm{~m})$, but it is also probable that a variety of mechanisms which vary across the depth gradient may be important in transmitting climatological variation to the benthic populations.

Correlation of winter air temperatures in Scandinavia with the NAO index has been shown by van Loon \& Rogers (1978). Similarly, Alheit \& Hagen (1996) have shown a significant positive correlation between the NAO index and west European air temperature anomalies, as well as a relation of the January air ternperature in England to the NAO index. Cushing (1982, Fig. 82) has published data from Betin (1957) on longterm winter ice cover in the Baltic. Superimposing the pattern of the NAO index shows a virtually complete correspondence of periods of low NAO index with high Baltic ice cover over the period 1880 to 1950 . The positive correlation between the NAO index and deep water temperature in the Skagerrak is demonstrated in Fig. 7 with temperature lagging the NAO index by 1 yr. Thus there exists a clear association of winter atmospheric temperature variation to ocean water temperature variation in the Skagerrak region, although the mechanisms driving this linkage may be complex (Alheit \& Hagen 1996).

Winter temperature variation may be one potential linkage from climate to the biological systems of the Skagerrak. Alheit \& Hagen (1996) have concluded that long-term climatic variation associated with severe winters drives variation in abundance patterns of herring (and alternating populations of sardines) along the Swedish coast. Long-term shifts in oceanic temperature regimes of coastal waters have also been implicated in variations of spawning pattern of a variety of pelagic species off California (MacCall \& Praeger 1988). Josefson et al. (1993) also noted the potential role of water temperature variation on the benthos of the 
Skagerrak-Kattegat. How low winter temperatures would be directly favorable to benthic populations is not clear. An indirect connection might occur if winter conditions are severe enough to cause mortality of bottom feeding fishes or macrocrustaceans, as was the case in the winter of 1962/63 in portions of the North Sea (Cushing 1982). Benthic populations might respond favorably to a release of predation pressure. Whether the strong negative correlation of crustacean landings and benthic population abundance (Fig. 11) is partially or wholly a result of trophic interactions or, as is probably the case for the positive correlation with cod landings (Fig. 10), is largely an independent response to climatic driven variation in the biological systems of the Skagerrak, cannot be determined at this time.

The potential for climatic variation to be an important influence on trophic interactions in coastal systems is suggested by both modeling (Robinson 1994) and empirical data (Aebisher et al. 1990), but the interactions are likely to be very complex. For example, Fromentin et al. (1998) found no correlation between abundance of 0-groups of cod or pollack and the NAO. while the fluctuations of Calanus finmarchicus in the Skagerrak were closely associated with the NAO.

The negative correlation between NAO index and stream flow (Fig. 8) provides the most probable mechanistic connection of climatic variation to variation in benthic populations. Josefson (1990) and Josefson et al. (1993) have previously demonstrated the positive relationship of nutrient input to the Skagerrak and Kattegat to flow volumes of coastal rivers in Sweden and land runoff in Denmark. Positive correlations were also shown between runoff and primary production levels in the Kattegat from 1970 to 1990. Josefson (1990) proposed that increased nutrients increased surface primary production in coastal waters and hence the food supply to benthic populations. During periods of low NAO values, winter precipitation in Scandinavia (Rogers 1984 ) is higher than average, and thus flow of nutrients into coastal waters will be increased. Increased production of phytoplankton with rapid sinking of production to the bottom in the shallower waters close to the coast (Smetacek 1980) should be reflected in a higher chemical oxygen demand in the bottom waters with some lag period. The negative correlation between oxygen concentration and stream flow (Fig. 9) is therefore consistent with this scenario. Table 3 also demonstrates the direct (or 1 yr lagged) positive correlation of the benthic communities in the Skagerrak with stream flow predicted by this mechanism. Smith (1996) has also shown that strong recruitment of the suspension feeding brittle star Amphiura filiformis at inshore stations $(20 \mathrm{~m})$ tends to follow periods of high river flow from Swedish rivers into the Kattegat.
Similar relationships appear to occur in the coastal embayments on the Swedish coast. Hagberg (1997) compared benthic infaunal data from a number of sites within Gullmarsfjorden over the 1980s and 1990s with measurements of yearly primary production between 1983 and 1992 from 1 site at the mouth of the fjord (Lindahl 1995). There was a positive correlation between NAO and primary production in this area, with a 1 yr lag of primary production (Hagberg 1997). These findings are consistent with the hypothesis that there is a linkage between the NAO, runoff driven primary production, and benthic community response at the offshore stations of the Skagerrak.

Preliminary examination of benthic data from the monitoring stations collected during the period 1995 to 1996 shows increases at most stations which is consistent with the pattern predicted from the 7 to $8 \mathrm{yr}$ cycle within the Skagerrak benthic communities observed over the last 25 yr. In the summer of 1997 the benthos in the deep basin of Gullmarsfjorden was severely disturbed by extremely low oxygen values due to a lack of water exchange. The last serious hypoxic disturbance occurred in 1989 to 1990 , i.e. 7 to 8 yr before the 1997 crash in the fjord macrobenthos. We do not mean to imply that there is a fixed temporal cycle to the NAO of 7 to 8 yr, merely that this has been the approximate cycle length over the recent period, which is not unexpected given the fact that the dominant oscillatory component of the index over $130 \mathrm{yr}$ is $7.9 \mathrm{yr}$.

The hypoxia events within Gullmarsfjorden have generally been attributed to increased local and regional eutrophication. However, the data presented within this study strongly suggest that periodic problems within the fjord may have an important component related to regional climatological variation which may influence stream flow and surface productivity, as well as deep water exchange, within the fjord.

In 1985 Rosenberg et al. (1987) revisited 23 of the benthic stations established by C. G. J. Petersen (Petersen 1913) in the northern Skagerrak and the Oslofjord and showed that a dramatic increase in biomass had occurred during the intervening period. The conclusion was that these changes pointed toward a general enrichment of the area, even though other potential causes also were discussed. Other studies in the 1970s and 1980s (Josefson. \& Smith 1984, Josefson 1990) also demonstrated large biomass increases in the region during these periods. Josefson $(1987,1990)$ concluded that the investigated area most likely was being affected by anthropogenic organic enrichment. However, our results suggest the importance of climatological oscillatory patterns as an influence on these benthic systems. Cyclical climatic changes may interact strongly with, or even overshadow, changes from 
anthropogenic alterations such as eutrophication. If the role of climatic variation is not considered, it may lead to incorrect conclusions regarding the relative contribution of anthropogenic versus naturally generated disturbances in regulating marine biological systems. The development of appropriate methods to separate climatic and anthropogenic contributions to long-term changes in benthic communities is a significant challenge for future research.

Acknowledgements. Financial support was primarily provided by the Swedish Environmental Protection Agency. We are especially grateful for the excellent support from Sverker Evans of the Swedish EPA. Stefan Agrenius processed most of the preserved material. J. C. Rogers provided the data for computation of the NAO index. Torbjön Lindkvist and Kurth Ehlert of the Swedish Meteorological and Hydrological Institute (SMHI) provided the stream flow data. The fisheries data were obtained from the Swedish Statistical Central Bureau. Thanks are due to William Ambrose and Jarl-Ove Strömberg for valuable comments on the manuscript.

\section{LITERATURE CITED}

Aebisher NJ, Coulson JC, Colebrook JM (1990) Parallel longterm trends across four marine trophic levels and weather. Nature 347:753-755

Alheit J, Hagen E (1996) The Bohuslän herring periods: are they controlled by climate variations or local phenomena? ICES Rep CM 1996/0:6

Barber RT, Chavez FP (1983) Biological consequenses of El Niño. Science 222:1203-1210

Baumgartner TM, Soutar A, Ferreira-Bartrina V (1992) Reconstruction of the history of Pacific sardine and northern anchovy populations over the past two millennia from sediments of the Santa Barbara basin, California. CalCOFI Rep 33:24-40

Beamish RJ, Riddell BE, Neville CEM, Thomson BL, Zhang Z (1995) Declines in chinook salmon catches in the Strait of Georgia in relation to shifts in the marine environment. Fish Oceanogr 4:243-256

Betin VV (1957) Ice conditions in the Baltic and its approaches and their long term variations. Trans State Oceanogr Inst $41: 54-125$

Botsford LW, Methot RD, Wilen JE (1982) Cyclic covariation in the California king salmon, Oncorhynchus tshawytscha, silver salmon, $O$. kisutch, and Dungeness crab, Cancer magister, fisheries. Fish Bull US 80:791-801

Cane MA (1983) Oceanographic events during El Niño. Science 222:1189-1195

Cushing DH (1981) Temporal variability in production systems. In: Longhurst AR (ed) Analysis of marine ecosystems. Academic Press, New York, p 443-471

Cushing DH (1982) Climate and fisheries. Academic Press, New York

Dayton PK, Tegner MJ (1984) Catastrophic storms, El Niño, and patch stability in a southern California kelp community. Science 224:283-285

Dickson RR, Kelly PM, Colebrook JM, Wooster WS, Cushing DH (1988) North winds and production in the eastern North Atlantic. J Plankton Res 10(1):151-169

Francis RC, Hare SR (1994) Decadal-scale regime shifts in the large marine ecosystems of the North-east Pacific: a case for historical science. Fish Oceanogr 3:279-291
Fromentin JM, Stenseth NC, Gjosceter J, Johannessen $T_{\text {, }}$ Planque B (1998) Long-term fluctuations in cod and pollack along the Norwegian Skagerrak coast. Mar Ecol Prog Ser 162:265-278

Gray JS (1990) Statistics and the precautionary principle. Mar Pollut Bull 21:174-176

Gray JS, Christie H (1983) Predicting long-term changes in marine benthic communities. Mar Ecol Prog Ser 13:87-94

Griffies SM, Bryan K (1997) Predictability of North Atlantic multidecadal climate variability. Science 275:181-184

Hagberg J (1997) The North Atlantic Oscillation and its influence on the soft bottom fauna in the Lysekil area, western Sweden. MSc thesis, Kristineberg Marine Research Station

Hansen DV, Bezdek HF (1996) On the nature of decadal anomalies in North Atlantic sea surface temperature J Geophys Res 101(C4):8749-8758

Johannessen T, Dahl E (1996) Declines in oxygen concentrations along the Norwegian Skagerrak coast, 1927-1993: a signal of ecosystem changes due to eutrophication? Limnol Oceanogr 41:766-778

Josefson AB (1987) Large-scale patterns of dynamics in subtidal macrozoobenthic assemblages in the Skagerrak: effects of a production-related factor? Mar Ecol Prog Ser 38:13-23

Josefson AB (1990) lncrease of benthic biomass in the Skagerrak-Kattegat during the 1970 s and 1980 s - effects of organic enrichment? Mar Ecol Prog Ser 66:117-130

Josefson $A B$, Jensen JN, Ertebjerg $G$ (1993) The benthos community structure anomaly in the late 1970 s and early 1980 s - a result of a major food pulse? J Exp Mar Biol Ecol $172: 31-45$

Josefson AB, Smith S (1984) Changes of benthos biomass in the Skagerrak-Kattegat during the 1970s: a result of chance events, climatic changes or eutrophication? Meddn Havsfiskelab, Lysekil 292:111-121

Kerr RA (1997) A new driver for the Atlantic's moods and Europe's weather? Science 275:754-755

Lindahl $O$ (1995) Long-term studies of primary production in the Gullmar Fjord, Sweden. In: Skjoldal HR, Hopkins C, Erikstad KE, Leinaas HP (eds) Ecology of fjords and coastal waters. Elsevier, Amsterdam

MacCall AD, Praeger MH (1988) Historical changes in abundance of six fish species off southern California, based on CALCOFI egg and larva samples. CALCOFI Rep 29:91-101

North Sea Task Force (1993) North Sea Subregion 8. Assessment Report 1993. State Pollution Control Authority, Oslo

Petersen CGJ (1913) Havets Bonitering. II. Om Havbundens Dyresamfund og om disses betydning for den marine Zoogeografi. Beret Minist Landbr Fisk Dan Biol Stn 21:1-42

Philander G (1989) El Niño and La Niña. Am Scient 77 : $451-459$

Robinson CLK (1994) The influence of ocean climate on coastal plankton and fish production. Fish Oceanogr 3: $159-171$

Rogers JC (1984) The association between the North Atlantic Oscillation and the Southern Oscillation in the Northern Hemisphere. Mon Weather Rev 112:1999-2015

Rosenberg R, Gray JS, Josefson AB, Pearson TH (1987) Petersen's benthic stations revisited: II. Is the Oslofjord and eastern Skagerrak enriched? J Exp Mar Biol Ecol 105: $219-251$

Smetacek V (1980) Annual cycle of sedimentation in relation to plankton ecology in western Kiel Bight. Ophelia Suppl 1:65-76

Smith SH (1996) Trends among echinoderms in a coastal area of the Kattegat, Sweden. In: Elefteriou A, Ansell AD, Smith CJ (eds) Proc 28th EMBS. Biology and ecology of 
coastal waters. Olsen \& Olsen, Fredensborg, p 323-332

Sokal RR, Rohlf FJ (1981) Biometry. The principles and practice of statistics in biological research, 2 nd edn. WH Freeman and Company, New York

Stein M, Lloret J (1995) Stability of water masses - impact on cod recruitment off West Greenland. Fish Oceanogr 4: 230-237

Sutton RT, Allen MR (1997) Decadal predictability of North Atlantic sea surface temperature and climate. Nature 388: $563-567$

Tarazona J, Salzwedel H, Arntz W (1988a) Oscillations of

Editorial responsibility: Otto Kinne (Editor),

Oldendorf/Luhe, Germany macrobenthos in shallow waters of the Peruvian central coast induced by El Niño 1982-83. J Mar Res 46 $593-611$

Tarazona J, Salzwedel H, Arntz W (1988b) Positive effects of 'El Niño' on macrobenthos inhabiting hypoxic areas of the Peruvian upwelling system. Oecologia 76:184-190

van Loon H, Rogers JC (1978) The seesaw in winter temperatures between Greenland and northern Europe. Part I: general description. Mon Weather Rev 106:296-31

Ware DM (1995) A century and a half of change in the climate of the NE Pacific. Fish Oceanogr 4:267-277

Submitted: January 2, 1998; Accepted: June 12, 1998 Proofs received from author(s): August 4, 1998 